3. Innovatsiini tekhnolohii navchannia (2017). [Innovative learning technologies]. Textbook manual for students. Higher technical educational institutions. (Ed.). Bakhtiiarova Kh.Sh.; scientific editor AristovaA.V.; Kyiv, 172 p. [in Ukrainian].

4. Kovalchuk, V. A. (2016). Teoretychni ta metodychni osnovy profesiinoi pidhotovky maibutnikh uchyteliv do roboty v umovakh variatyvnosti osvitnovykhovnykh system [Theoretical and methodological bases of professional training of future teachers to work in the conditions of variability of educational systems]. Doctor's thesis. Zhytomyr, 514 p. [in Ukrainian].

5. Kutsenko, V. (2014). Ekolohichna osvita vazhlyvyi instrument staloho rozvytku [Environmental education is an important tool for sustainable development]. Economics of nature management and environmental protection. No. 214. pp. 2022. [in Ukrainian].

6. Nisimchuk, A. S., Boichuk, P. M \& Panasiuk, O. P. (2012). Innovatsiini tekhnolohii pedahohichnoi osvity [Innovative technologies of pedagogical education]. Lutsk, 480 p. [in Ukrainian].

7. Romaniuk, I. (2016). Uprovadzhennia innovatsiinoi osvitnoi diialnosti u navchalnomu zakladi [Introduction of innovative educational activities in the educational institution]. The practice of managing an educational institution. No. 2. pp. 23-33. [in Ukrainian].

Стаття надійшла до редакції 25.09.2020

УДК 504.37.013

DOI:

Надія Стецула, кандидат біологічних наук, доцент кафедри екології та географії Дрогобиџького державного педагогічного університету імені Івана Франка

\title{
ЕКОЛОГІЗАЦІЯ ОСВІТИ ЯК КЛЮЧОВА ТЕНДЕНЦІЯ СТАЛОГО РОЗВИТКУ СУСПІЛЬСТВА
}

У статті проаналізовано екологізацію освіти як соціальну й педагогічну проблему. Оцінено нормативно-правові документи державного регулювання реалізації Міжнародних екологічних стратегій та програм. Встановлено, щуо екологізація освіти передбачає формування системних, комплексних, інтегрованих екологічних знань з питань охорони довкілля, екологічної етики з метою досягнення сталого розвитку суспільства, а також навичок ї застосування на практичі. Схарактеризовано основні складові змісту екологічної освіти.

Ключові слова: екологізачія; екологічні знання; сталий розвиток; екологічна освіта; охорона довкілля; екологічна етика.

Jim. 24.

Nadiya Stetsula, Ph.D.(Biology), Associate Professor of the Ecology and Geography Department, Drohobych Ivan Franko State Pedagogical University

\section{ECOLOGIZATION OF EDUCATION AS A KEY TREND OF SUSTAINABLE DEVELOPMENT OF SOCIETY}

The article considers the greening of education as a pedagogical problem. The normative-legal documents of the state regulation of the implementation of the International strategies and programs are evaluated. It is established that the greening of education involves the formation of systematic, comprehensive, integrated environmental knowledge on environmental protection, environmental ethics in order to achieve sustainable development of society, as well as practical skills for their application. The main components of the content of environmental education are given. The most important source of scientific worldview is the science of ecology, and the world is comprehended in the process of scientific knowledge and the process of education.

Environmental education has such specific indicators as environmental education is one of the factors in overcoming the current environmental crisis; the uniqueness of environmental education, as it sets its goals in a new way. The most important goal of environmental education is the formation of environmental culture; in environmental education in a new way is the selection of content, as it is characterized by the principle of "new synthesis", which has a special methodological significance (meaning the synthesis of all human knowledge about nature, knowledge about conservation and optimization of the environment). Environmental education has a prognostic focus on caring for nature and preserving living conditions for future generations.

Global environmental problems have been clearly outlined at the turn of the millennium, putting modern civilization on the brink of self-destruction.

The corresponding reaction of society to the degradation of the natural environment is manifested in the 
global trend of development of the modern world - greening, due to the penetration of environmental ideas into science, technology, culture in general. The influence of environmental education on this scientific style of thinking, human consciousness is manifested in a holistic and synthetic coverage of the phenomena of the biosphere.

Keywords: greening; ecological knowledge; sustainable development; an ecological education, environmental protection; ecological ethics.

П остановка проблеми. Екологізація суспільної діяльності та людської свідомості - це проблема, що останнім часом набула статусу найбільш актуальної з-поміж інших, якими переймається людство. Сьогодні відчутний системний тиск комплексу глобальних екологічних проблем, які змінюють структурно-функціональну організацію біосфери загалом й умови існування людства зокрема. Ці проблеми є результатом стихійного розвитку процесів взаємодії природи та суспільства, проявляються у виснаженні природних ресурсів, забрудненні довкілля, порушенні динамічної рівноваги в біогеоценозах, таксономічній структурі біологічного різноманіття, незворотних змінах у генетичних структурах живих організмів тощо.

Потреба регулювання процесу взаємодії природи та суспільства й управління ним на часі $\epsilon$ очевидною, тому зумовлює необхідність консолідації зусиль широких кіл громадськості в масштабах як окремих країн, регіонів, так і світу загалом. Без транскордонного впливу, без співробітництва сторін й укладення міжнародних договорів і угод, спрямованих на вироблення узгодженої політики, програм і стратегій неможливо забезпечити стратегію розв'язання та розумну регуляцію аналогічних процесів на різних ієрархічних рівнях біологічних систем.

Глобальні екологічні проблеми чітко окреслилися на межі тисячоліття, поставивши сучасну цивілізацію на межу самознищення. У преамбулі Міжнародної декларації “Хартія Землі - 2000” зазначається: “Ми перебуваємо на критичному етапі в історії Землі, коли людство має визначитися 3 власним майбутнім ... Для подальшого розвитку ми повинні ... об'єднатися заради сталої глобальної спільноти, заснованої на пошані до природи, загальних правах людини, економічній справедливості та культурі миру" [23].

Відповідна реакція суспільства на деградацію природного середовища проявилася у глобальній тенденції розвитку сучасного світу - екологізації, завдяки проникненню екологічних ідей в науку, техніку, культуру загалом $[18,26]$. Екологічна проблематика відчутно впливає на всі сфери життя людей: науку, виробництво, політику, економіку, енергетику, охорону здоров'я й освіту, на формування основних світоглядних орієнтацій сучасної людини, визначаючи стиль їі мислення.
Вплив екологічної освіти на цей науковий стиль мислення, людську свідомість проявляється у цілісному та синтетичному охопленні явищ біосфери $[1,86]$. Звідси, актуальною $є$ проблема екологізації освіти, яка передбачає формування у молодого покоління системних, комплексних знань і компетентностей у царині охорони довкілля та екологічної етики задля досягнення сталого розвитку суспільства.

Аналіз основних досліджень та публікацій. Аналіз літератури засвідчує інтерес науковців до різних аспектів екологізації освіти. Проблему екологізації освітнього простору, ії перспективи висвітлено у працях О. Бондаренка [1], Н. Пустовіт [4], В. Крисаченка [7]; роль екологічної освіти для реалізації засад сталого розвитку наведено у путівнику В. Підліснюка [21]; особливості відносин у системі "природа - суспільство людина" описано у публікаціях С. Рудишина [19], М. Мойсеєва [9], М. Реймерса [18].

Метою статті $\epsilon$ аналіз особливостей процесу екологізації освіти як ключової тенденції сталого розвитку суспільства.

Виклад основного матеріалу. Під час взаємодії у системі “людина - суспільство природа" природа виступає у двох основних модифікаціях: як первісно-незаймана та матеріально-змінена людиною, в яких та й інша продовжують існувати і функціонувати на основі співдії. Людина зацікавлена передовсім у раціональному матеріальному перетворенні природи, однак це неможливо реалізувати без пізнання законів природи $[6,63]$. Не слід забувати, що панування людини над природою полягає у тому, що люди, на відміну від тварин, вміють пізнавати ії закони і правильно їх застосовувати $[2 ; 6]$. Звідси продуктивним результатом свідомої діяльності людини є не лише матеріальні продукти, а й знання особливостей природних процесів як наслідок ідеального перетворення природи.

Уплив природи на суспільство та вплив суспільства на природу як сторони реальної взаємодії природи і суспільства не існують у відриві й незалежно один від одного. Ця обставина має бути стрижневою при дослідженні процесу взаємодії природи і суспільства. Вплив природи на суспільство в дійсності має настільки ж історичний характер, як і зворотний вплив суспільства на природу. 
Упродовж людської історії здійснюється формування сфери взаємодії природи та суспільства як цілісної системи. Генеза екологічної освіти та підходи до виділення періодів iii впливу на цивілізацію яскраво висвітлені у наукових працях В. Крисаченка [7] та М. Мойсеєва [9]. Спеціальне дослідження періодизації еволюції взаємодії природи та суспільства здійснив С. Рудишин, з'ясувавши роль екологічної освіти у формуванні екологічної свідомості людини залежно від соціальноекономічних умов. Так, зокрема, науковець виділяє чотири основні етапи еволюції: “1) донауковий етап, котрий відображений у легендах і міфах давньогрецького періоду; 2) пізньому Середньовіччю, що характеризується накопиченням й осмисленням природничих знань, які заклали підгрунтя методологічних засад взаємодії екологічної та педагогічної наук; 3) становлення і розвиток екології як самостійної наукової галузі (кінець XIX - середина XX ст.); 4) новий етап, котрий розпочинається з середини 60-х pp. ХX ст. та визначається загальним загостренням взаємовідносин між суспільством і природою. Виникає соціальна екологія, яка інтегрує природничі й гуманітарні аспекти екологічних проблем; формується екологічна освіта і виховання в сучасному вигляді" $[19,375]$.

Відтак сучасний етап взаємодії природи та суспільства, що розпочався в середині ХХ ст., невіддільний від науково-технічного прогресу. Цей п'ятий етап став етапом паритетних відносин в системі “природа - суспільство -людина", основою якого $є$ реалізація концептуальних засад сталого розвитку суспільства. Принагідно зазначимо, що сталий розвиток визначається як економічне зростання, за якого ефективно розв'язуються найважливіші проблеми життєзабезпечення суспільства без виснаження, деградації та забруднення довкілля [22]. Звідси, головною особливістю цього етапу $є$ те, що взаємодія природи і суспільства у всіх своїх проявах набуває глобального характеру.

Сучасна постановка проблеми взаємовідносин природи та людини виявляється у розриві між безмежними потенційними можливостями виробничої діяльності й обмеженими ресурсними і компенсаторними можливості біосфери. У суспільній свідомості завжди були представлені протилежні традиції, які полягають у “підкоренні природи" або “поклонінні природі". При всій полярності цих ціннісних установок вони мають спільний імператив, згідно 3 яким природа розглядається як щось зовнішнє стосовно людини. На думку А. Матвійчука [8], Г. Науменка [10], докорінна зміна у взаєминах людини та природи можлива лише за умов створення нової системи цінностей, при якій природа розглядатиметься як самоцінність, як світ самої людини, як предметне буття їі суспільної сутності.

Уперше про необхідність захисту природи й раціональне використання природних ресурсів було заявлено в 1972 р. на Всесвітній зустрічі з навколишнього середовища, котра відбулася в Стокгольмі. Через десятиліття, 1983 р. Організацією Об’єднаних Націй була створена Всесвітня комісія 3 навколишнього середовища і розвитку. У іiі доповіді вперше в узагальненому вигляді була інтерпретована важлива дефініція - “сталий розвиток”. Так, зокрема, під сталим розвитком голова комісії Г. Брутланд запропонував розглядати такий розвиток, котрий “задовольняє потреби теперішнього часу, але не ставить під загрозу здатність майбутніх поколінь задовольняти свої власні потреби" [3, 326].

Концепція сталого розвитку спочатку виникла в країнах Західної Свропи, а наприкінці XX ст. поширилася на більшість країн світу. В їі становленні та реалізації чітко простежуються три етапи [5]:

- перший пов'язаний $з$ усвідомленням необхідності вироблення ідеології людства зі збереження динамічної рівноваги у взаємодії природи і суспільства;

- другий передбачає підготовку нормативноправових документів щодо забезпечення сталого розвитку, їх обговорення та прийняття на Конференції Організації Об'єднаних Націй з навколишнього середовища і розвитку (Бразилія, Ріо-де-Жанейро, 1992);

- третій уможливлює реалізацію у всіх країнах світу принципів сталого розвитку, згідно з якими планета Земля розглядається як спільний дім людства, як цілісний організм, усі складові якого поєднані функціонально-енергетичними зв'язками.

На шляху досягнення сталого розвитку, міжнародною спільнотою визначено низку політичних, економічних і соціальних вимог, що випливають із його принципів. Згідно 3 цими вимогами, енергія та матеріали отримуються 3 відновлюваних або перероблених джерел, а відходи виробництва і споживання мають бути мінімальними, переробка вторинних ресурсів всеохопною. Ці вимоги також визначають необхідність максимального стримування процесу зростання міст і зменшення їх впливу на навколишнє середовище, обмеження споживання енергії та ресурсів. Ключовою вимогою сталого розвитку є визнання необхідності комплексного розв'язання екологічних проблем із залученням 
до співпраці представників національних урядів, неурядових організацій, представників бізнесу та місцевої влади, науковців науково-дослідних центрів й університетів [11].

Після завершення роботи Конференції у Ріоде-Жанейро (1992) рух щодо забезпечення сталого розвитку суспільства набуває потужного імпульсу. На європейському рівні проходить низка важливих міжнародних форумів: Перша Свропейська конференція 3 питань сталого розвитку міст Європи (Данія, м. Ольбург, 1994 ) та Друга Свропейська конференція з питань сталого розвитку міст (Португалія, м. Лісабон, 1996), на яких був закладений фундамент й окреслена методологія забезпечення сталого розвитку в Європі. У 2002 р. відбулася Третя Свропейська конференція (Німеччина, м. Ганновер), на якій зроблено важливу заяву про активну підтримку сталого розвитку міст на рівні регіональної, національної, європейської та загалом міжнародної політики.

Важливою подією в 2002 р. стала Всесвітня зустріч на вищому рівні зі сталого розвитку (Південна Африка, м. Йоганнесбург), на якій була прийнята Йоганнесбургська декларація зі сталого розвитку. У параграфі 111 цієї декларації наголошується на “...необхідності створення і зміцнення системи науки й освіти для сталого розвитку на усіх рівнях із метою обміну знаннями, досвідом і передовою практикою та створення наукового потенціалу” [21, 25]. У декларації було підтверджено прихильність народів світу до сталого розвитку, побудови гуманного й справедливого глобального суспільства; було підкреслено важливе значення стійкого розвитку охорони довкілля та соціально-економічного благополуччя. Водночас було відзначено експонентне зростання шкоди навколишньому середовищу, що проявляється в зменшенні біорізноманіття, виснаженні природних ресурсів, опустелюванні, зміні клімату, стихійних лихах; заявлено про необхідність створення умов для задоволення потреб людей у чистій воді, енергії, збереженні здоров'я, продовольчій безпеці й охороні біологічного різноманіття; наголошено на важливості для цивілізації та народів світу діалогу і співпраці, незалежно від раси, релігії, мови, культури і традицій.

В Україні, відповідно до рішень Конференцій ООН зі сталого розвитку, розпочалася підготовка відповідних нормативно-правових документів, що стосувалися стратегії сталого розвитку країни. Першим документом стала Постанова Верховної Ради України "Про Концепцію сталого розвитку населених пунктів”, прийнята у 1999 р. [13]. На жаль, розроблені проєкти Законів про Концепцію переходу України до сталого розвитку $(2001,2004)$ так і не були прийняті [16; 17]. Лише у 2015 р. Указом Президента України була введена в дію Стратегія сталого розвитку “Україна - 2020”, в якій заплановано здійснення 62 реформ та програм розвитку, а також визначено 25 індикаторів, за якими має оцінюватися результативність реалізації цієї Стратегії [15].

3-поміж основних напрямів переходу України до сталого розвитку, стало створення нормативноправової бази, спрямованої на формування ефективної системи пропаганди ідей сталого розвитку та екологізацію виробництва й освіти. Так, за підтримки Міністерства освіти і науки та наполяганням численних екологічних товариств Верховною Радою України був прийнятий закон "Про концепцію екологічної освіти в Україні" (№ 13/6-19 від 20 грудня 2001 р.). Згідно 3 положеннями цієї Концепції, екологічна освіта має стати важливою складовою сталого суспільного розвитку. Зокрема, в ній вказується, що одним із найголовніших важелів у розв'язанні нагальних екологічних проблем має стати “підготовка громадян з високим рівнем екологічних знань, екологічної усвідомленості та культури на основі новіших критеріїв оцінювання взаємовідносин людського суспільства й природи (не насильство, а гармонійне співіснування з нею)" [12].

На думку О. Бондаренка [1], Н. Пустовіт [4], В. Підліснюка [21], екологічна освіта створює методологічну основу для прогнозування наслідків втручання у природні системи, синтезу знань i соціального досвіду, вивчення можливостей впровадження засад сталого розвитку. Крім того, нині інтегративні тенденції в екологічній науці зумовлюють появу нових наукових напрямів, значно розширюють межі екологічних досліджень, включають до проблемного поля науки соціальну екологію, філософію екології та антропоекологію, екологічну етику й естетику.

Так, соціальна екологія вивчає динамічну структуру та механізм взаємодії природи i суспільства, його історію, основні тенденції й закономірності розвитку. Соціальна екологія особлива наука, яка орієнтує на оптимальну взаємодію суспільства і природи. Практична потреба в соціальній екології виникає лише тоді, коли об'єктом дослідження виступає сама взаємодія природи і суспільства. Соціальна екологія покликана здійснити симбіоз соціальноекологічних досліджень в єдину картину взаємодії природи і суспільства [20, 25].

Сьогодні вважається доречним і навіть “модним” безоглядно критикувати теорії 
антропоцентризму та водночас захищати правомірність позиції екоцентризму; поширювати ідеї про те, що “все природне $\epsilon$ самоцінним і має право на існування “просто так”, незалежно від корисності або марності та навіть шкідливості для людини" [2, 38; 7]. Нам імпонують погляди знаних учених, які вважають, що крайній екоцентризм і натуралізм тією ж мірою неспроможні, в якій неспроможними є крайній соціологізм й антропоцентризм, що ігнорують закони природи.

Власне, оптимізація екологічної взаємодії становить специфічне завдання сучасних екологічних досліджень. Їх розв'язання спрямоване на забезпечення потрібного людині та суспільству регулювання цією взаємодією, створення умов, при яких можливі мінімізація негативних і максимізація позитивних результатів діяльності людей. Управління екологічною взаємодією не означає абсолютного підкорення природних процесів волі людей. Воно передбачає досягнення можливих у цих умовах станів стійкості та розвитку, сталого саморозвитку компонентів, котрі максимально відповідають інтересам природи, людини і суспільства.

У наш час екологія стала одним із інтегральних чинників розвитку наукових галузей, адже вона настільки розкриває фундаментальні сторони існування людства, що змушує науковців розглядати іï як постійну проблему з єдиною методологічною орієнтацією, достатньо вираженими тенденціями до синтезу усього розмаїття знань про природу і навіть залученням основних законів соціального розвитку. Чимало вчених (М. Мойсеєв [9], М. Реймерс [18] та ін.) вважають екологію міждисциплінарним науковим напрямом саме тому, що в ній чітко виражені різні нові віяння сучасної науки, зокрема: всебічне діалектичне охоплення досліджуваного об'єкта в його розвитку; комплексність і рівнозначність всіх напрямів, що входять до цього дослідницьког комплексу; перехід від компонентного аналізу до системного; ймовірно-статистичний характер знань тощо.

Водночас В. Крисаченко зазначає, що освіта за своєю суттю $є$ вторинною щодо науки, релігії, філософії, котрі створюють, описують й інтерпретують нову картину світу [7]. Ця картина світу, що містить глобальні проблеми людства, 3 неминучістю приводить до необхідності нової освіти, яку, по праву, можна назвати екологічною [24]. Звідси, від фрагментарних екологічних знань, що мали місце в 70-80 pp. XX ст., сучасне педагогічне співтовариство перейшло до розуміння необхідності формування у молодого покоління фундаментальних екологічних знань та глобально-орієнтованого світогляду, згідно з яким світ розглядається як:

1) єдина система, що включає глобальний, регіональний і локальний рівні;

2) інтегрована система, заснована на багатовимірних взаємозв'язках між окремими підсистемами;

3) саморегулювальна система, що передбачає наявність гомеостазу, балансу та врівноваженості;

4) розвивальна система, зміни в якій останнім часом набувають білыш динамічного, всеохоплюючого і водночас суперечливого характеру;

5) відкрита система, пов'язана з Космосом.

Специфічними ознаками екологічної освіти $\epsilon$ те, що:

- по-перше, вона виступає одним із чинників подолання сучасної екологічної кризи, а їі унікальність полягає у тому, що вона по-новому ставить свої цілі та знаходить механізми їх досягнення;

- по-друге, головною метою сучасної екологічної освіти виступає формування екологічної культури особистості;

- по-третє, в екологічній освіті по-новому відбувається відбір змісту, адже їй притаманний принцип “нового синтезу”, що має особливе методологічне значення (мається на увазі синтез усіх знань людства про природу, знань щодо збереження й оптимізації довкілля);

- по-четверте, екологічна освіта має прогностичну спрямованість, пов'язану 3 турботою про природу і збереженням умов життя для прийдешніх поколінь людей.

Нині екологічна освіта - пріоритетний напрям розвитку системи освіти в Україні. Усвідомлення не лише наукових, а й моральних, правових аспектів взаємодії людини з природою є основою становлення екологічної культури особистості. На екологізації освіти як одному з ключових напрямів державної політики наголошується в "Національній стратегії розвитку освіти в Україні на період до 2021 року”. У ній зазначається, що “стрижневим завданням освіти у XXI ст. $є$ розвиток мислення, орієнтованого на майбутнє. Відповідно, стратегія розвитку національної системи освіти повинна формуватися адекватно сучасним інтеграційним і глобалізаційним процесам, вимогам переходу до постіндустріальної цивілізації, що забезпечить стійкий рух та розвиток України у першій чверті XXI ст., інтегрування національної системи освіти в європейський і світовий освітній простір" [14]. Звідси, новий підхід до екологічної освіти вимагає передовсім розвитку екологічної свідомості, виховання особистості з екологічним, глобально орієнтованим світоглядом. 
Висновки. Нові політичні та соціальноекономічні умови, що склалися в Україні, диктують необхідність істотного підвищення екологічної культури, формування екологічної самосвідомості особистості як визначальних маркерів цивілізованості. Стрімкий розвиток екологічної освіти у другій половині ХХ ст. став адекватною реакцією суспільства на погіршення стану довкілля та швидке виснаження природних ресурсів. Екологічна освіта має життєво важливе значення, адже формує у молодої людини знання про закони природи, причини та наслідки екологічних катастроф і лих, сприяє розвитку ціннісних орієнтацій та розуміння прав на сприятливі умови життя і як результат уможливлює сталий розвиток суспільства та держави.

Формування глобально-орієнтованого світогляду, при якому акцент переноситься на розуміння взаємозв' язків живої і неживої природи, сутності взаємодії природи та людини має важливе значення для пошуку розв'язання одвічної суперечності освіти, що полягає в необхідності формування у молодої людини наукового світогляду на основі знань про цілісну картину світу та необхідності професійної спеціалізації освіти.

Екологічне виховання, екологічна грамотність та екологічна культура молоді стають необхідними умовами переходу сучасної цивілізації до моделі сталого розвитку. Рухливість і нестійкість природного та соціокультурного просторів диктують нові вимоги до освітніх систем, спрямовані на формування і задоволення потреби суспільства й особистості в екологічній культурі та екологічній освіті.

\section{ЛIТЕРАТУРА}

1. Бондаренко О. В. Проблеми формування екологічної свідомості в сучасних умовах. Весник Малой академии наук Криворожского подразделения Европейского университета финансов, информационных систем, менеджмента и бизнеса. 2001. № 1 (1). С. 80-87.

2. Борейко В.Е. История охраны природы в Украине (Х в. - 1980 г.) : в 2 т. Киев : Эколого-культ. центр, 1997. Т. $1:$ Х век - 1941 год. $304 \mathrm{c}$.

3. Брундтланд Г. Наше спільне майбутнє: Міжнародна комісія 3 навколишнього середовища та розвитку: монографія. Оксфорд : Оксфорд Юніверсіті Пресс, 1987. 512 c.

4. Екологізація освітнього простору сучасної загальноосвітньої школи : монографія / Н. Пустовіт, О. Колонькова, О. Пруцакова, Г. Тарасюк, Ю. Солобай. Харків : “Друкарня Мадрид”, 2016. 154 с.

5. Комісія ООН із сталого розвитку. URL: http:// www.iisd.ca/linkages/topics/csd/

6. Коммонер Б. Замыкающийся круг. Природа, человек, технология: монография. Ленинград : Гидрометиздат, 1974. 296 с.

7. Крисаченко В. С. Екологічна культура: теорія i практика: монографія. Київ : Заповіт, 1996. 350 с.

8. Матвійчук А. В. Екологічне знання та стиль мислення сучасної науки: монографія. Рівне, 2002. 147 с.

9. Моисеев Н.Н. Историческое развитие и экологическое образование : монография. Москва : МНЭПУ, 1995. $132 \mathrm{c}$.

10. Науменко Г. Г. Екологічна культура та її виміри. Нова парадигма: журнал наукових пращьь. 2007. № 69. C. $45-57$.

11. Основи стійкого розвитку: навч. посіб. / за ред. Л.Г. Мельника. Суми : “Університетська книга”, 2005. $654 \mathrm{c}$.

12. Про концепцію екологічної освіти в Україні. Закон України від 20.12.2001 13/6-19. URL: https:// zakon.rada.gov.ua/rada/show/v6-19290-01\#Text

13. Про Концепцію сталого розвитку населених пунктів. Постановою Верховної Ради України від 24 грудня 1999 року № 1359-XIV. URL: https:// zakon.rada.gov.ua/laws/ show/1359-14\#Text

14. Про Національну стратегію розвитку освіти в Україні на період до 2021 року. Указ Президента України від 25 червня 2013 року № 344/2013. URL: https:// zakon.rada. gov.ua/laws/show/344/2013\#Text

15. Про Стратегію сталого розвитку “Україна - 2020”. Указ Президента України від 12 січня 2015 року № 5/ 2015. URL: https://zakon.rada.gov.ua/laws/show/5/ 2015\#Text

16. Проект Закону про Концепцію переходу України до сталого розвитку від 19.12.2001. № 3234-1. URL: http:/ /w1.c1.rada.gov.ua/pls/zweb2/ webproc4 1?pf3511=11647

17. Проект Постанови про Концепцію переходу України до сталого розвитку від 02.07.2004. № 5749 URL: ht tp://w 1.c1.rada.gov.ua/p1s/zweb2/ webproc4 2? id $=\& p f 3516=5749 \&$ skl $=5$

18. Реймерс Н.Ф. Экологизация. Введение в экологическую проблематику: учеб. пособ. Москва : УРАО, 1997. $132 \mathrm{c}$.

19. Рудишин С. Філософські основи екологічної освіти: генезис, сучасні тенденції розвитку. Філософія освіти, 2011. 1-2 (10). С. 375-389.

20. Соціальна екологія: навч. посіб. / за ред. Л.П. Царика. Тернопіль : підручники і посібники, 2002. $208 \mathrm{c}$.

21. Сталий розвиток суспільства: роль освіти: путівник / В. Підліснюк та ін. ; за ред. В. Підліснюк. Київ : СПД “Ковальчук”, 2005. 88 с.

22. Трегобчук В. Концепція сталого розвитку для України. Вісник НАН Украӥни. 2002. № 2. С. 28-40.

23. Хартія Землі. URL: www.earthcharter.org

24. Stetsula N.O., Pavliukh S.B. To the ecological culture through ecological education Acta Carpatica. Rzeszow : Integracja њrodowisk naukowych obszaru pogranicza polsko-ukraicsritgo. 2015. Vol. 24. P. 217-222.

\section{REFERENCES}

1. Bondarenko, O. V. (2001). Problemy formuvannia ekolohichnoi svidomosti $\mathrm{v}$ suchasnykh umovakh. 
[Problems of formation of ecological consciousness in modern conditions]. Bulletin of the Small Academy of Sciences of the Kryvyi Rih branch of the European University of Finance, Information Systems, Management and Busines. No. 1 (1). pp. 80-87. [in Ukrainian].

2. Boreyko, V.Ye.(1997). Istoriya okhrany prirody $\mathrm{v}$ Ukraine (X v. $-1980 \mathrm{~g}$.) $: \mathrm{v} 2 \mathrm{t}$. [History of nature protection in Ukraine (X century-1980): in 2 vols.]. Kyiv, 304 p. [in Russian].

3. Brundtland, H. (1987). Nashe spilne maibutnie: Mizhnarodna komisiia z navkolyshnoho seredovyshcha ta rozvytku [Our common future: the International Commission on Environment and Development]. Oksford, 512 p. [in Ukrainian].

4. Pustovit, N., Kolonkova, O., Prutsakova, O., Tarasiuk, H. \& Solobai, Yu. (2016). Ekolohizatsiia osvitnoho prostoru suchasnoi zahalnoosvitnoi shkoly [Greening of the educational space of a modern secondary school]. Kharkiv, 154 p. [in Ukrainian].

5. Komisiia OON iz staloho rozvytku [Commission UN on Sustainable Development]. Available at: $\underline{\mathrm{http}: / /}$ www.iisd.ca/linkages/topics/csd/ (accessed 20 Nov. 2020). [in Ukrainian].

6. Kommoner, B. (1974). Zamykayushchiysya krug. Priroda, chelovek, tekhnologiya [Closing circle. Nature, man, technology]. Leningrad, 296 p. [in Russian].

7. Krysachenko, V. S. (1996). Ekolohichna kultura: teoriia i praktyka [Ecological culture: theory and practice]. Kyiv, 350 p. [in Ukrainian].

8. Matviichuk, A. V. (2002). Ekolohichne znannia ta styl myslennia suchasnoi nauky [Ecological knowledge and style of thinking of modern science]. Rivne, $147 \mathrm{p}$. [in Ukrainian].

9. Moiseev, N.N. (1995). Istoricheskoe razvitie i ekologicheskoe obrazovanie [Historical development and environmental education]. Moscov, 132 p. [in Russian].

10. Naumenko, H. H. (2007). Ekolohichna kultura ta yii vymiry [Ecological culture and its dimensions]. A new paradigm: a journal of scientific papers. No. 69. pp. $45-$ 57. [in Ukrainian].

11. Osnovy stiikoho rozvytku (2005). (Ed.). Melnyk L.H. [Fundamentals of sustainable development]. Sumy, $654 \mathrm{p}$. [in Ukrainian].

12. Pro kontseptsiiu ekolohichnoi osvity v Ukraini [On the concept of environmental education in Ukraine]. Law of Ukraine from 20.12.2001 13/6-19. Available at: https:// zakon.rada.gov.ua/rada/show/v6-19290-01\#Text (accessed 21 Nov. 2020). [in Ukrainian].

13. Pro Kontseptsiiu staloho rozvytku naselenykh punktiv [About the Concept of sustainable development of settlements]. Resolution of the Verkhovna Rada of
Ukraine 24.12.1999. No. 1359-XIV (accessed 21 Nov. 2020). Available at: https://zakon.rada.gov.ua/laws/show/135914\#Text [in Ukrainian].

14. Pro Natsionalnu stratehiiu rozvytku osvity v Ukraini na period do 2021 roku [On the National Strategy for the Development of Education in Ukraine until 2021]. Decree of the President of Ukraine from 25.06.2013. No. 344/2013 (accessed 21 Nov. 2020). Available at: https:// zakon.rada.gov.ua/laws/show/344/2013\#Text [in Ukrainian].

15. Pro Stratehiiu staloho rozvytku "Ukraina - 2020" [On the Sustainable Development Strategy "Ukraine 2020"]. Decree of the President of Ukraine from 12.01.2015 (accessed 21 Nov. 2020). No. 5/2015. Available at: https:// zakon.rada.gov.ua/laws/show/5/2015\#Text [in Ukrainian].

16. Proekt Zakonu pro Kontseptsiiu perekhodu Ukrainy do staloho rozvytku No. 3234-1 vid 19.12.2001 [Draft Law on the Concept of Ukraine's Transition to Sustainable Development] (accessed 21 Nov. 2020). Available at: http:/ /w1.c1.rada.gov.ua/pls/zweb2/webproc4 1 1?pf3511=11647 [in Ukrainian].

17. Proekt Postanovy pro Kontseptsiiu perekhodu Ukrainy do staloho rozvytku No. 5749 vid 02.07.2004. [Draft Resolution on the Concept of Ukraine's Transition to Sustainable Development No. 5749 from 02.07.2004] (accessed 21 Nov. 2020). Available at: http:// w1.c1.rada.gov.ua/pls/zweb2/webproc4 2?id=\&pf3516 $=$ 5749 \&skl $=5$ [in Ukrainian].

18. Reymers, N.F. (1997). Ekologizatsiya. Vvedenie v ekologicheskuyu problematiku [Greening. Introduction to environmental issues]. Moscov, 132 p. [in Russian].

19. Rudyshyn, S. (2011). Filosofski osnovy ekolohichnoi osvity: henezys, suchasni tendentsii rozvytku [Philosophical bases of ecological education: genesis, modern tendencies of development]. Philosophy of education. No. 1-2 (10). pp. 375-389. [in Ukrainian].

20. Sotsialna ekolohiia (2002). (Ed.). Tsaryk L.P. [Social ecology]. Ternopil, 208 p. [in Ukrainian].

21. Stalyi rozvytok suspilstva: rol osvity (2005). (Ed.). Pidlisniuk V. [Sustainable development of society: the role of education]. Kyiv, 88 p. [in Ukrainian].

22. Trehobchuk, V. (2002). Kontseptsiia staloho rozvytku dlia Ukrainy [The concept of sustainable development for Ukraine]. Bulletin of the NAS of Ukraine. No. 2.pp. 28-40. [in Ukrainian].

23. Khartiia Zemli [Charter of the Earth] (accessed 21 Nov. 2020). Available at: www.earthcharter.org [in Ukrainian].

24. Stetsula, N.O. \& Pavliukh, S.B. (2015). To the ecological culture through ecological education. Acta Carpatica. Rzeszow. Vol. 24. pp. 217-222. [in English].

Стаття надійшла до редакції 21.10.2020

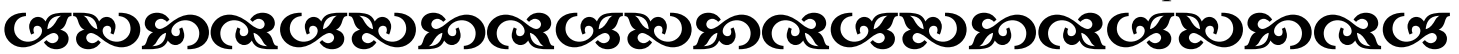

“Дюдина не є володарем всього навколо, а сама є частиною природи та об” єктом для тих самих космічних сил, що контролюють всі інші борми життя”.

Рейчел Карсон

американсьқа біологиня, письменниия

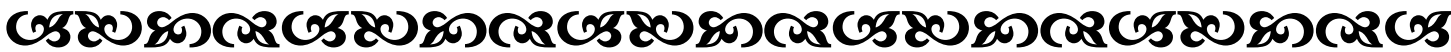

